\title{
RESPIRAÇÃO, MASTIGAÇÃO E DEGLUTIÇÃO DE CRIANÇAS RESPIRADORAS ORAIS SUBMETIDAS À ADENOTONSILECTOMIA
}

\author{
Maria Fernanda Bagarollo, Aniely de C. Pereira *
}

\section{Resumo}

O modo respiratório é alterado quando há a presença de hipertrofia de tonsilas palatina e faríngeas. A cirurgia de adenotonsilectomia é um importante procedimento utilizado para tratamento nos casos de hipertrofias das tonsilas. $O$ presente estudo tem como objetivo investigar e comparar, além da respiração, outras funções estomatognáticas como mastigação e deglutição, em crianças respiradoras orais submetidas a cirurgia de adenotonsilectomia em momentos pré e pós cirúrgico com crianças respiradoras nasais. Para esse estudo as crianças foram subdivididas em faixas etárias e aplicado o Protocolo de Avaliação Miofuncional Orofacial com Escores. A partir do estudo foi possível concluir que as hipertrofias de tonsilas apresentam consequências, não somente na respiração, mas também em outras funções do sistema estomatognático.

\section{Palavras-chave: \\ Adenotonsilectomia, crianças, respiração}

\section{Introdução}

As tonsilas estão regularmente associadas a atividades imunológicas e por isso propensas a infecções bacterianas, que é um dos principais fatores causadores da hipertrofia de tonsilas ${ }^{1}$. Essa hipertrofia de tonsilas acomete as funções do sistema estomatognático, como obstrução das vias aéreas, podendo comprometer o padrão respiratório e diminuir a qualidade de vida do sujeito $^{2}$. E além de alteração na respiração, a hipertrofia das tonsilas também pode afetar as outras funções do sistema estomatognático, como a mastigação e a deglutição ${ }^{2,3}$. É importante ressaltar que a população mais afetada por esta hipertrofia é a pediátrica ${ }^{1,3}$. Com embasamento nessas considerações, o presente estudo tem como objetivos avaliar as funções do sistema estomatognático pré e pós- cirúrgico, comparar as faixas etárias das crianças submetidas à cirurgia e, a partir disso, comparar as idades e reavaliar a melhor faixa etária para a indicação cirúrgica. Com isso, verificar se a idade interfere na recuperação espontânea das crianças.

\section{Resultados e Discussão}

No presente estudo foram avaliadas 30 crianças do Grupo Controle (GC), sendo 18 meninos e 12 meninas, e 33 crianças do Grupo Estudo (GE), sendo 21 meninos e 12 meninas. As crianças foram subdivididas em grupos por faixas etárias. No GC foram coletadas 20 crianças de 3 a 5 anos; 7 de 6 a 8 anos e 3 de 9 a 12 anos. No GE foram coletadas 19 crianças de 3 a 5 anos; 9 de 6 a 8 anos e 5 de 9 a 12 anos. Foram aplicados nessas crianças o Protocolo de Avaliação Miofuncional Orofacial com Escores (AMIOFE) e parte do Protocolo MBGR para avaliação da fala. Os dados foram registrados através de filmagens, tabulados e tratados estatisticamente. $\mathrm{O}$ estudo faz parte de um projeto maior com continuidade de dois anos e, portanto, os dados pós cirúrgicos ainda estão sendo coletados.
A partir dos dados coletados, os resultados obtidos foram alterações nas funções estomatognáticas do grupo estudo respiradores orais, os quais apresentaram menor força mastigatória, bolo alimentar anteriorizado, uso de líquido para ajudar na deglutição, deglutições múltiplas, dificuldade para mastigar e deglutir bolo muito duro, escolhendo alimentos moles e retirando da boca o bolo antes de finalizar mastigação.

Os resultados também mostraram alterações nas estruturas orais, como arcada dentária do GE. Porém, em estruturas como a mandíbula, não estavam alteradas em ambos os grupos. A fala do GE apresentou produção oral com presença de distorções por musculatura flácida. Já o GC apresentou alterações na fala esperadas para a faixa etária em algumas crianças e atraso na fala em outras.

\section{Conclusões}

Há alterações nas funções estomatognáticas em crianças com hipertrofia de tonsilas, se comparadas com o grupo controle.

\section{Agradecimentos}

\section{AME/Santa Bárbara d' Oeste e Sae/Unicamp}

1.BRODSKY, L. O Tecido Linfático do Anel de Waldeyer: Tonsilas Palatinas, Nasofaríngeas e Linguais. IX Manual de Otorrinolaringologia Pediátrica na IAPO. São Paulo: Editora e Grafica Vida\&Consciência, 2010. p.69 - 79. 2.BERALDIN, B.S.; RAYES, T. R.; VILLELA, P. H.; RANIERI, D. M. Avaliação do impacto da adenotonsilectomia sobre a qualidade de vida em crianças com hipertrofia das tonsilas palatinas e faríngeas. Rev. Bras. Otorrinolaringol. 2009, vol.75, n.1, pp.64-69.

3.FUKUCHI, I. et al. Perfil psicológico de crianças submetidas a adenoidectomia e/ou amigdalectomia no pré e pós operatório. Revista Brasileira de Otorrinolaringologia, v. 71, n. 4, p. 521-525, 2005. 